\title{
Penerapan tutor sebaya menggunakan metode diskusi untuk meningkatkan hasil belajar matematika siswa kelas V SDN 02 Mesoyi
}

\author{
Wawan Junari \\ SD Negeri 02 Mesoyi Talun Kab. Pekalongan
}

\begin{tabular}{ll}
\hline Article Info & ABSTRACT \\
\hline Article history: & $\begin{array}{l}\text { The purpose of this study was to determine whether the application of the peer } \\
\text { tutor learning model using the discussion method could improve student }\end{array}$ \\
$\begin{array}{l}\text { Received : 30 Agustus 2021 } \\
\text { Revised : 21 September 2021 } \\
\text { Accepted : 28 September 2021 }\end{array}$ & $\begin{array}{l}\text { to the fifth grade students of SDN 02 Mesoyi as many as 20 students. This } \\
\text { research was designed in two cycles, each cycle carried out in the stages of } \\
\text { planning, implementation, observation, and reflection. The results of this study } \\
\text { indicate that peer tutoring learning using the discussion method with LKS } \\
\text { media can improve students' cognitive abilities in solving problems, teacher } \\
\text { performance is able to carry out learning with peer tutor learning models using } \\
\text { discussion methods with LKS media well. Suggestions in this study is that } \\
\text { teachers should use peer tutor learning models using discussion methods with } \\
\text { LKS media can be used as an alternative to improve student learning } \\
\text { outcomes. }\end{array}$ \\
\hline outcomes &
\end{tabular}

(*) Corresponding Author:

wawan.jnr@gmail.com

How to Cite: Junari, W. (2021). Penerapan tutor sebaya menggunakan metode diskusi untuk meningkatkan hasil belajar matematika siswa kelas V SDN 02 Mesoyi. Action Research Journal, 1(1): 142-147.

\section{PENDAHULUAN}

Pendidikan memegang peranan penting karena sesuatu yang sangat diperlukan oleh individu kapan dan dimanapun ia berada. Pendidikan merupakan suatu usaha untuk mempersiapkan manusia melalui kegiatan pengajaran, bimbingan, dan latihan bagi peranannya di masa mendatang (Ahdiyat, 2015). Oleh karena itu perkembangan di bidang pendidikan pada hakikatnya mencerdaskan dan meningkatkan kualitas sumber daya manusia. Matematika sebagai salah satu ilmu dasar dewasa ini juga telah berkembang amat pesat, baik materi maupun kegunaan. Matematika sekolah adalah matematika yang diajarkan di pendidikan dasar dan pendidikan menengah. Matematika tersebut terdiri atas bagian matematika yang dipilih guna menumbuhkembangkan kemampuan dan membentuk pribadi siswa serta berpedoman pada perkembangan ilmu pengetahuan dan teknologi (Hastari, 2019).

Berdasarkan pengalaman selama mengajar di kelas V SDN 02 Mesoyi, Talun masalah yang sering dihadapi adalah banyak siswa pasif dan menggantungkan pada siswa yang pandai saja, akibatnya pada saat mengerjakan soal soal banyak siswa yang tidak dapat mengerjakannya. Dampaknya adalah hasil belajar yang rendah. Guru harus mampu memilih model pembelajaran yang sesuai dengan materi pelajaran sehingga dapat mempermudah siswa mencerna pelajaran yang disampaikan oleh guru karena penyajian guru yang menarik. Salah satu cara untuk mengatasi masalah diatas adalah dengan menggunakan teknik tutor sebaya untuk melaksanakan proses belajar matematika, selain itu diperlukan juga pembelajaran yang penuh motivasi dan membangkitkan motivasi serta memaksimalkan semua indera yang dimiliki supaya siswa dapat terlibat secara langsung dalam pembelajaran (Ahdiyat, 2015; Izzati, 2015). Tutor sebaya adalah sumber belajar selain guru, yaitu teman sebaya lebih pandai memberi bantuan belajar kepada teman yang mengalami kesulitan dalam memahami bahan pelajaran yang dipelajari (Suprijadi, 2015). 
Abineno, Rowa, \& Jagom (2019) menyatakan bahwa metode belajar yang paling baik adalah dengan mengajarkan kepada orang lain. Oleh karena itu pemilihan model pembelajaran tutor sebaya sebagai strategi pembelajaran akan sangat membantu siswa di dalam mengajarkan materi pada teman-temannya. Pembelajaran matematika melalui kegiatan tutor sebaya adalah model pembelajaran kooperatif yang memberikan keuntungan baik pada siswa kelompok bawah maupun kelompok atas yang bekerja menyelesaikan tugas-tugas dari guru. Siswa kelompok atas akan menjadi tutor bagi siswa kelompok bawah dan kelompok sedang, sehingga siswa kelompok bawah dan kelompok sedang memperoleh bantuan khusus di teman sebaya yang memiliki orientasi dan bahasa yang sama (Hayati et al., 2018; Kusuma, 2017).

Langkah-langkah model pembelajaran tutor sebaya sebagai berikut: 1) Pilihlah materi yang memungkinkan materi tersebut dapat dipelajari siswa secara mandiri. 2) Bagilah siswa menjadi kelompok-kelompok yang heterogen, siswa-siswa pandai disebar dalam setiap kelompok dan bertindak sebagai tutor sebaya, 3) Masing-masing kelompok diberi tugas mempelajari satu sub materi, setiap kelompok dipandu oleh siswa yang pandai sebagai tutor sebaya. 4) Berikan mereka waktu yang cukup untuk persiapan dan setiap kelompok melalui wakilnya menyampaikan sub materi sesuai dengan tugas yang diberikan guru bertindak sebagai nara sumber utama. 5) Setelah semua kelompok melaksanakan tugasnya, beri kesimpulan dan klarifikasi seandainya ada pemahaman yang perlu diluruskan (Kusuma, 2017; Padmayani et al., 2017).

Berdasarkan latar belakang tersebut, rumusan masalah dalam penelitian ini adalah: Apakah penerapan pembelajaran tutor sebaya menggunakan metode diskusi dapat meningkatkan hasil belajar siswa kelas V SDN 02 Mesoyi, Talun?

\section{METODE}

Penelitian tindakan kelas ini dilaksanakan di SDN 02 Mesoyi, Talun dengan subjek penelitian adalah siswa kelas V. Penelitian tindakan kelas adalah salah satu strategi pemecahan masalah yang memanfaatkan tindakan nyata dalam bentuk proses pengembangan inovatif dalam mendeteksi suatu permasalahan (Arikunto, 2002). Penelitian yang dilakukan direncanakan dalam dua siklus, setiap siklus terdiri dari empat kegiatan, yaitu: perencanaan, pelaksanaan, observasi dan refleksi.

Pengambilan data dalam penelitian ini melalui dua cara, yaitu non tes dan tes. Data non tes diperoleh dengan pengamatan secara langsung menggunakan lembar partisipasi siswa dan lembar observasi. Sedangkan tes hasil belajar digunakan untuk mengukur kemampuan siswa dalam menyelesaikan soal. Data hasil pembelajaran yang diambil dengan memberikan tes kepada siswa setelah pelaksanaan siklus. Tes dilaksanakan pada siklus pembelajaran dan akhir siklus.

Untuk mengetahi seberapa besar keaktifan dan kerjasama siswa dalam mengikuti proses belajar mengajar. Analisis ini dilakukan pada instrumen lembar observasi dengan menggunakan teknik deskriptif melalui persentase. Data mengenai hasil belajar dari kemampuan kognitif siswa dalam menyelesaikan soal dianalisis dengan cara menghitung rata-rata nilai dan ketuntasan belajar klasikal. Indikator keberhasilan dalam penelitian ini adalah:

1. Siswa dapat memecahkan masalah materi himpunan dengan ketuntasan individu minimal 65 dan ketuntasan belajar klasikal minimal 85\% dari jumlah siswa.

2. Keaktifan siswa dalam kegiatan pembelajaran, dikatakan berhasil jika kriteria keberhasilan dikategorikan baik dengan prosentase mencapai $\geq 75 \%$.

3. Kemampuan guru dalam membuat rancangan pembelajaran dan penerapan dalam kelas, dikatakan berhasil jika kemampuan guru mencapai prosentase $\geq 75 \%$.

\section{HASIL DAN PEMBAHASAN}

Hasil

Setelah persiapan dilakukan, maka langkah selanjtnya adalah pelaksanaan penelitian. Penelitian ini dirancang dalam dua siklus, dan tahapan siklus terdiri atas tahapan perencanaan, tindakan, pengamatan, dan refleksi. Adapun tahapan tiap siklus adalah sebagai berikut: 
Siklus I

1. Perencanaan

a. Menyiapkan rencana pembelajaran dengan model pembelajaran tutor sebaya

b. Menentukan kolaborasi dengan teman sejawat sebagai partner penelitian

c. Merancang LKS, tes akhir pertemuan, soal pekerjaan rumah, tes akhir siklus.

2. Pelaksanaan tindakan

a. Guru menyampaikan materi pelajaran

b. Guru membagi siswa menjadi beberapa kelompok dan satu siswa yang bertindak sebagai tutor sebaya.

c. Guru membagikan Lembar Kerja Siswa (LKS) untuk dikerjakan secara berkelompok.

d. Guru meminta setiap kelompok untuk menyajikan hasil pekerjaannya di depan kelas.

e. Guru bersama siswa menympulkan hasil belajar

f. Guru memberikan tes akhir siklus I.

3. Pengamatan

Data ini diambil dari lembar pengamatan guru dengan menggunakan pembelajaran tutor sebaya menggungkan metode diskusi. Hasilnya menunjukkan bahwa:

a. Penguasaan materi sudah baik

b. Keterampilan guru menerapkan pembelajaran dengan model tutor sebaya menggunakan metode diskusi sudah baik

c. Kemampuan guru membimbing siswa dalam berdiskusi dan mengerjakan lembar kerja cukup baik

d. Kemampuan guru dalam menjawab pertanyaan siswa cukup baik

e. Kemampuan guru dalam memberikan dorongan dan motivasi pada siswa dalam mengerjakan tugas cukup baik

f. Pengelolaan alokasi waktu cukup baik

g. Dalam melakukan pengajaran, persentase yang diperoleh guru mencapai $72 \%$ dengan kategori cukup baik.

\section{Refleksi}

Setelah melaksanakan pengamatan atas tindakan pembelajaran dikelas, selanjutnya diadakan refleksi terhadap segala kegiatan yang telah dilakukan. Berdasarkan hasil pengamatan pada siklus I diperoleh bahwa :

a. Guru perlu menyusun materi ajar dengan runtut untuk disampaikan ke siswa sehingga dapat dipahami oleh siswa. Apabila ada siswa yang mengajukan pertanyaan guru dapat menjawab dengan baik. Selain itu guru juga dapat mengambil kesimpulan dari apa yang telah disampaikan ke siswa dengan baik

b. Agar tercipta suasana pembelajaran yang aktif, maka guru harus melibatkan siswa. Misalnya dengan memberikan kesempatan pada siswa untuk berpendapat atau mungkin memberi pertanyaan kepada siswa

c. Guru sudah menggunakan model pembelajaran tutor sebaya menggunakan metode diskusi dengan baik

d. Agar siswa mampu menjawab pertanyaan dari guru, maka guru dianjurkan untuk mengulang kembali materi yang dianggap belum jelas oleh siswa.

e. Berdasarkan hasil pengamatan dari siklus I diperoleh saat pelaksanaan tutor sebaya, siswa yang kurang pandai terlalu pasif dan menggantungkan jawabannya pada siswa yang pandai saja, akibatnya pada saat mengerjakan soal tes evaluasi yang dikerjakan secara individu siswa yang kurang pandai tidak bisa mengerjakan soal dengan benar. Ini sejalan dengan hasil pengamatan keaktifan siswa yang hanya mencapai persentase $60 \%$ dengan kategori cukup. Oleh karena itu guru harus lebih membimbing dan mengarahkan bahkan memotivasi agar selalu aktif dan bekerjasama dalam kelompok. Sedangkan hasil tes menunjukkan bahwa siswa yang tuntas belajar sebanyak 13 siswa dengan persentase ketuntasan belajar $65 \%$ dan rata-rata hasil belajar siswa sebesar 68,3. Dalam pembelajaran siklus I belum berhasil atau belum memenuhi kriteria ketuntasan belajar secara klasikal. 
Siklus II

\section{Perencanaan}

Berdasarkan hasil refleksi siklus I baik yang berkaitan denan guru, siswa maupun perangkat diadakan perencanaan ulang yang meliputi:

a. Identifikasi masalah dan perumusan masalah berdasarkan refleksi

b. Menyiapkan materi menggunakan pembelajaran tutor sebaya

c. Menyiapkan rencana pembelajaran

d. Menyusun lembar observasi baik untuk siswa maupun untuk guru. Observasi direncanakan akan dilaksanakan tiap pertemuan dan dilakukan oleh observer.

e. Merancang kembali lembar kerja siswa dan tes akhir formatif.

2. Pelaksanaan tindakan

a. Guru menyampaikan materi pelajaran

b. Guru membagi siswa menjadi beberapa kelompok dan satu siswa yang bertindak sebagai tutor sebaya.

c. Guru membagikan Lembar Kerja Siswa (LKS) untuk dikerjakan secara berkelompok.

d. Guru meminta setiap kelompok untuk menyajikan hasil pekerjaannya di depan kelas.

e. Guru bersama siswa menympulkan hasil belajar

f. Guru memberikan tes akhir siklus II.

3. Pengamatan

Data ini diambil dari lembar pengamatan guru menggunakan pembelajaran tutor sebaya bermetode diskusi. Hasilnya menunjukkan bahwa:

a. Penguasaan materi sudah baik

b. Keterampilan guru menerapkan pembelajaran dengan model tutor sebaya menggunakan metode diskusi sudah baik

c. Kemampuan guru membimbing siswa dalam berdiskusi dan mengerjakan lembar kerja dengan baik

d. Kemampuan guru dalam menjawab pertanyaan siswa sangat baik

e. Kemampuan guru dalam memberikan dorongan dan motivasi pada siswa dalam mengerjakan tugas sudah baik

f. Pengelolaan alokasi waktu baik

g. Dalam melakukan pengajaran, persentase yang diperoleh guru mencapai $85 \%$ dengan kategori sangat baik.

4. Refleksi

Dengan melihat kekurangan-kekurangan yang ada pada siklus I, maka pada siklus II dilakukan perbaikan pada bagian yang kurang maksimal. Pada siklus II ini ada peningkatan yang mengarah pada ketercapaian indikator keberhasilan pada penelitian tindakan kelas ini. Hasil pengamatan dari siklus II diperoleh bahwa aktivitas siswa telah meningkat yaitu pengamatan keaktifan siswa yang mencapai persentase $78 \%$ dengan kategori baik. Peningkatan ini disebabkan karena kemampuan guru dalam menerapkan pembelajaran tutor sebaya menggunakan metode diskusi lebih baik. Disamping itu kemampuan guru dalam memberikan motivasi dan menumbuhkan interaksi antar siswa juga lebih baik dari siklus I. Sehingga siswa juga terlihat lebih aktif dalam kegiatan kelompok untuk ikut menjelaskan pada teman sekelompoknya yang belum bisa menyelesaikan soal. Siswa juga telah beradaptasi dengan siswa sekelompoknya sehingga tidak canggung lagi untuk bertukar pikiran dan mengeluarkan pendapat. Berdasarkan hasil tes dari siklus II diperoleh bahwa siswa yang tuntas belajar sebanyak 17 siswa dengan persentase ketuntasan belajar $85 \%$ dan rata-rata hasil belajar siswa sebesar 75,8. Dalam pembelajaran siklus II berhasil memenuhi kriteria ketuntasan belajar secara klasikal.

\section{Pembahasan}

Berdasarkan hasil penelitian menunjukkan penerapan tutor sebaya dengan menggunakan metode diskusi dapat meningkatkan hasil belajar matematika siswa. Hal ini ditunjukkan dengan 
terjadinya peningkatan hasil belajar yaitu dari 20 siswa, 13 siswa tuntas menjadi 17 siswa tuntas belajar. Nilai rata-rata kelas 68,3 menjadi 75,8 rata-rata kelas tersebut dengan presentase ketuntasan belajar secara klasikal 85\%. Hal ini dikarenakan kemampuan kognitif siswa semakin meningkat, siswa mampu memahami konsep materi, serta mampu menganalisis dan mampu mencari penyelesaiannya (Ahdiyat, 2015; Izzati, 2015).

Berdasarkan hasil penilaian lembar observasi kinerja guru pada awalnya guru hanya memperoleh skor rata-rata $72 \%$ dengan kriteria cukup baik meningkat menjadi $85 \%$ dengan kriteria sangat baik. Hal ini dikarenakan guru telah dapat memberikan motivasi lebih agar siswa mampu bekerjasama dalam kelompoknya. Meningkatnya bimbingan dan perhatian guru pada tiap-tiap kelompok pada proses pembelajaran berlangsung akan membuat siswa lebih aktif. Disamping itu, guru sudah mampu menciptakan suasana kondusif dan mampu menciptakan suasana pembelajaran aktif sehingga proses pembeajaran berlangsung dengan lancar (Suprijadi, 2015).

Berdasarkan pembahasan diatas Penelitian Tindakan Kelas dengan menggunakan tutor sebaya dengan metode diskusi dapat meningkatkan hasil belajar siswa yang berupa kemampuan kognitif siswa dalam memecahkan masalah dan kemampuan guru dalam mengajar, sehingga keaktifan siswa juga dapat meningkat. Pembelajaran tutor sebaya dengan menggunakan metode diskusi lebih aktif pada setiap kegiatan pembelajaran seperti belajar kelompok, berdiskusi, berbagi bersama dan berinteraksi dengan temannya karena dalam pembelajaran ini guru lebih berperan sebagai mediator (Hayati et al., 2018; Kusuma, 2017). Siswa lebih mudah memahami materi karena dalam pembelajaran tutor sebaya ini salah satu siswa yang pandai menerangkan pada siswa yang kurang pandai, dan bagi siswa yang kurang pandai apabila terjadi kesulitan atau kurang memahami materi tidak ada rasa malu untuk bertanya (Hastari, 2017). Jadi model pembelajaran ini sangat tepat diterapkan dalam pembelajaran agar siswa lebih aktif dan keaktifan dalam proses belajar mengajar.

\section{PENUTUP}

bahwa:

Berdasarkan hasil penelitian tindakan kelas yang telah dilaksanakan, dapat disimpulkan

1. Pembelajaran tutor sebaya menggunakan metode diskusi dapat meningkatkan hasil pembelajaran matematika siswa. Ini terlihat peningkatan rata-rata hasil belajar siswa dari siklus I ke siklus II, peningkatan jumlah siswa yang tuntas belajar dan peningkatan persentase ketuntasan belajar secara klasikal.

2. Pembelajaran tutor sebaya menggunakan metode diskusi dapat meningkatkan kinerja guru pada siklus I ke siklus II meningkat mencapai persentase 85\% dengan kategori sangat baik.

3. Pembelajaran matematika dengan menerapkan tutor sebaya juga dapat meningkatkan keaktifan siswa selama berdiskusi kelompok.

\section{DAFTAR PUSTAKA}

Abineno, P., Rowa, Y. R., \& Jagom, Y. O. (2019). Pengaruh Model Pembelajaran Tutor Sebaya terhadap prestasi belajar matematika siswa. ASIMTOT: Jurnal Kependidikan Matematika, 1(1), 61-67.

Ahdiyat, M. (2015). Metode Tutor Sebaya Untuk Meningkatkan Hasil Belajar Matematika Pada Materi Pengolahan Data. Faktor: Jurnal Ilmiah Kependidikan, 1(2).

Arikunto, S. (2002). Penelitian Tindakan Kelas. Jakarta: Rajawali Press.

Hastari, R. C. (2019). Penerapan Strategi Tutor Sebaya dalam Meningkatkan Motivasi Belajar Matematika. Abdimas: Jurnal Pengabdian Masyarakat Universitas Merdeka Malang, 4(1), 46-50.

Hayati, Y. L. S., Djatmika, E. T., \& As'ari, A. R. (2018). Pengaruh Model Pembelajaran Tutor Sebaya terhadap Kemampuan Komunikasi Matematis Siswa Sekolah Dasar. Jurnal Pendidikan: Teori, Penelitian, Dan Pengembangan, 3(8), 1056-1058. 
Izzati, N. (2015). Pengaruh penerapan program remedial dan pengayaan melalui pembelajaran tutor sebaya terhadap hasil belajar matematika siswa. Eduma: Mathematics Education Learning and Teaching, 4(1).

Kusuma, A. C. (2017). Efektifitas Pembelajaran Tutor Sebaya Berbantuan Modul Untuk Meningkatkan Komunikasi Matematik Mahasiswa. Cakrawala: Jurnal Pendidikan, 11(1), $1-8$.

Padmayani, K. P., Wiarta, I. W., \& Made Putra, M. P. (2017). Pengaruh Model Problem Based Learning Berbantuan Tutor Sebaya terhadap Hasil Belajar Matematika Siswa Kelas V. Mimbar PGSD Undiksha, 5(2).

Suprijadi, D. (2015). Pengaruh Tutor Sebaya Terhadaap Hasil Belajar Matematika Siswa Kelas VII SMP Daarussalaam Jakarta. Faktor Exacta, 3(2), 127-135. 